Article

\title{
Is Gender Inequality a Barrier to Economic Growth? A Panel Data Analysis of Developing Countries
}

\author{
Amaia Altuzarra (D), Catalina Gálvez-Gálvez * (D) and Ana González-Flores (iD \\ Department of Public Policies and Economic History, University of the Basque Country (UPV/EHU), \\ 48015 Bilbao, Spain; amaia.altuzarra@ehu.eus (A.A.); ana.gonzalezflores@ehu.eus (A.G.-F.) \\ * Correspondence: catalina.galvez@ehu.eus
}

Citation: Altuzarra, A.; Gálvez-Gálvez, C.; González-Flores, A. Is Gender Inequality a Barrier to Economic Growth? A Panel Data Analysis of Developing Countries. Sustainability 2021, 13, 367. https://doi.org/ $10.3390 /$ su13010367

Received: 3 November 2020 Accepted: 29 December 2020 Published: 3 January 2021

Publisher's Note: MDPI stays neutral with regard to jurisdictional clai$\mathrm{ms}$ in published maps and institutional affiliations.

Copyright: (C) 2021 by the authors. Licensee MDPI, Basel, Switzerland. This article is an open access article distributed under the terms and conditions of the Creative Commons Attribution (CC BY) license (https:// creativecommons.org/licenses/by/ $4.0 /)$.

\begin{abstract}
This study provides empirical evidence about the effects of various dimensions of gender inequalities (education, labour market and institutional representation) on economic growth. We use data from the World Bank Development Indicators database for the period 1990-2017. We initially use a large panel of 105 developing countries. Subsequently we study a panel with the sub-Saharan African (SSA) countries since this region is one of the poorest regions in the world. We estimate crosscountry and panel regressions. The results suggest that gender equality in education contributes to economic growth and this is a common feature in developing countries. The contribution of equality in education to growth seems to be greater in the SSA countries than in the entire sample of developing countries. The female-male ratio of labour market participation is not statistically significant. We also find a significant link between the presence of women in parliaments and growth in the sample of all developing countries, while this relationship is negative for the SSA countries. It is likely that despite the increased participation of women in the political arena in these countries, women may still encounter major obstacles to altering political priorities and affecting economic growth
\end{abstract}

Keywords: economic growth; gender inequality; education; labour force; women in parliament; dynamic panel data; SSA countries

\section{Introduction}

In 2015, 193 countries adopted the 2030 Agenda for Sustainable Development with 17 Sustainable Development Goals (SDGs), in which various goals refer, to a greater or lesser degree, to the gender discrimination issue. For example, Goal 4 refers to education with particular emphasis on the need to endeavour to make further progress towards achieving universal education goals. The world has achieved equality in primary education between girls and boys, but few countries have achieved that target at all levels of education [1]. Goal 5 focuses specifically on achieving equality and empowering women. This goal recommends that governments should ensure the equal participation of women in decision-making positions, whether political, economic or social [2]. Goal 8 encourages the creation of more egalitarian labour markets for women. The idea behind this international commitment is that facilitating access for women to the education and labour market as well as to political and economic bodies in conditions of equality will contribute to build sustainable economies and societies.

The relationship between gender inequality and economic development is an issue of growing concern in academic, economic and political spheres. According to some authors, gender inequality could hinder economic growth. For example, a large part of the literature argues that gender inequalities in education lead to underutilisation of human capital, which could also affect economic growth through channels whose effects are widely discussed in the literature [3-5]. However, other researchers argue that gender inequalities can have positive effects on the development of a country [6,7]. The negative 
association between female education and economic growth could partially be explained by the negative impact women's education has on the fertility rate, which would lower the stock of human capital in the next generation [8].

Gender inequalities in the labour market may have, according to part of the literature, effects on economic growth similar to the gender gap in education [9]. However, some authors claim that in export-oriented industries, the low pay of the female labour force may increase the country's competitiveness by reducing production costs, which would encourage exports and stimulate investment by improving the profitability of producers. This increase in investment and exports should boost economic growth [10].

More recently, a few researchers have started to look at whether gender differences in institutional political representation could hinder economic growth [11,12]. The rationale behind this hypothesis is the idea that women are less corrupt than men $[13,14]$ and tend to be more concerned with the needs of women, contributing to reducing gender inequalities and, thereby, fostering economic growth. However, the effect of female public representation on economic growth has scarcely been addressed within the literature and the empirical evidence is very limited and inconclusive. Furthermore, most of the few existing research studies have some drawbacks as they use econometric specifications that do not adequately allow for potential endogeneity problems or do not cover recent periods.

Given the scarce empirical literature on the relationship between economic growth and the three abovementioned dimensions of gender inequalities taken together, the purpose of this paper is to provide empirical evidence about whether the inequality in women's institutional representation, along with gender gaps in education and the labour market, have an impact on income per capita growth. We use data from the World Bank Development Indicators database during the period 1990-2017. The study is first based on a simple cross-country regression using Ordinary Least Squares (OLS) models and thereafter panel data and dynamic models are applied, GMM (Generalized Method of Moments). We first study a large panel made up of 105 developing countries. Subsequently, we complement our study by focusing on the group of sub-Saharan Africa (SSA) countries. We focus on this subsample because this region, as well as being the poorest, shows more gender inequalities than the other developing regions. According to the Human Development Report [15], the Gender Inequality Index (GII) and the Poverty Index (PI) of this region were 0.573 and 0.315 , respectively, the highest of the world regions.

Some of the contributions of this paper are as follows. First, it extends the empirical literature on the gender inequality-economic growth relationship by providing new empirical evidence, as the available evidence to date is neither abundant nor entirely conclusive. In order to bridge this gap, we propose a growth model including the three dimensions of gender inequalities, paying special attention to the participation of women in the political arena as we assume that being a member of parliament provides women with the opportunity to influence decisions about economic development. What little empirical research there is on this topic fails to be conclusive, though it points to there being no statistically significant or positive relationship between the two variables. We believe that the relationship between these variables is a matter for empirical investigation. Second, our empirical evidence is based on a dynamic growth model using data from a large panel of 105 developing countries covering the years 1990-2017. We employ the Generalized Method of Moments (GMM) estimation methodology, which takes into account potential problems of endogeneity, unobserved heterogeneity and autocorrelation. Much of the work on economic growth uses cross-section or fixed-effect models, which either do not control for the existence of endogeneity or do not do so adequately. It is claimed that the potential endogeneity of some explanatory variables in economic growth equations undermines the validity of results. Third, we assess whether the nexus between growth and the three dimensions of gender inequalities differs in the two groups of countries: developing countries and the least developing ones, such as those in the SSA region. This distinction is important, as the effect of gender inequalities on economic growth may vary according to the level of economic development. 
Overall, the study is relevant because there has been little empirical research that takes into account all the three types of gender inequalities considered together. In addition, the scarce number of studies on the extent to which real GDP responds to women's political representation reaches uncertain conclusions. This may have important policy implications, namely, whether there is still room for governments to strengthen women's access to education and the labour market, and whether measures to bring women into the political arena (e.g., adoption of electoral quotas) have contributed to economic growth.

The rest of the paper is organised as follows. The next section presents a review of the literature on the relationship between gender inequality and economic growth. Section 3 describes the data and methods. The estimation results and discussion are presented in Section 4 and in the last section, we draw the main conclusions.

\section{Theoretical Considerations on Gender Inequality and Economic Growth}

\subsection{Overview of Economic Growth Models}

Different theoretical perspectives have explained economic growth. Neoclassical models attributed economic growth to exogenous factors such as capital accumulation, which was achieved through savings [16]. Later models underlined the role of endogenous factors (human capital and technology) as key factors behind fostering productivity and growth [17-19]. Subsequently, other variables were added, such as trade openness as well as institutional and cultural factors. More recently, gender inequalities have been included in growth models with the aim of moving towards models that take into account some elements relating to sustainability.

In the neoclassical theory of economic growth, the rate of economic growth is a function of the initial conditions of the economy. The conditional convergence hypothesis states that, all things being equal, countries with lower GDP per capita will grow faster due to higher marginal returns from the capital stock. Growth also depends on capital accumulation, which affects growth in different ways. First, since the demand for investment goods is part of the aggregate demand in the economy, an increase in the demand for investment, provided that this demand is not satisfied by imports, will stimulate the production of investment goods that in turn will lead to economic growth. Second, capital formation improves the productive capacity of the economy so that the economy can produce more production. Third, investment in new plants and machinery increases productivity growth by introducing new technologies, which will also foster economic growth [20]. Theoretically, the contribution of investment to economic growth has invariably been considered as positive.

Regarding the relationship between trade openness and growth, there is so far neither theoretical nor empirical consensus. In the neoclassical model, changes in openness can only affect the pattern of product specialisation but not the long-term economic growth rate. In the new growth theory, by contrast, changes in trade openness can influence long-term economic growth rates, though the impact on growth is not clear when trading partners are different in terms of their innovation performance. Grossman and Helpman [21] described a model in which trade between a developed country and a less developed country, subject to a number of conditions, can improve the long-term growth rate in the poor countries. Young [22] and Stokey [23] showed that trade between a developed country and a poor country can reduce the long-term growth rates in the latter country. Spilimbergo [24], in turn, presented a model in which trade between advanced countries and developing countries can lower the long-term growth rate of developed countries.

Empirically, the consensus is also weak. Some authors found a positive link between both variables $[3,13,25-27]$. On the contrary, other studies revealed a negative relationship between trade openness and long-term growth rate in the sense that they found a positive relationship between tariffs and long-term rates of growth [28-30]. It is argued that most of this empirical evidence has shortcomings arising mainly from poor data quality and inappropriate econometric techniques [31-33]. 
It should be noted that international trade might have a different impact on men and women. The spread of globalisation may have changed the global division of labour between developed and developing countries, affecting women and men differently. Greater openness, on the one hand, can increase exports in developing countries, reducing the gap between skilled and unskilled workers, which would improve the relative salary of women (who normally provide unskilled labour). On the other hand, greater commercial openness can increase the demand for skilled workers and negatively affect the wage gap between both types of workers (see Wood [34] for Latin America). Since women tend to be overrepresented in the unskilled labour force, trade liberalisation does not necessarily reduce inequalities between men and women [35].

The relationship between economic growth and gender inequality has been discussed in the literature from different approaches. In the following sections, we focused on three main dimensions of gender inequalities: education, the labour market, and women's representation in public institutions.

\subsection{Inequalities in Education and Economic Growth}

Several theoretical and empirical studies have been focused on the relationship between gender inequality in education and economic growth. Early studies suggested that gender inequality in education could positively affect economic growth [6,7], by finding that a higher level of women's education is negatively correlated with economic growth. However, most studies indicated that gender inequality has a negative effect on growth $[3,4,8,36-43]$.

Literature provides various arguments in favour of the positive influence of women's education and gender equality on economic growth. Low levels of gender inequality in education raise the average quantity and quality of human capital by improving productivity and, therefore, economic growth $[3-5,8,38,44,45]$. Low gender inequality also has indirect effects on economic growth via its effects on fertility rates, infant mortality and children's health and education [36,37,40,42,43,46-50]. An improvement in the education level of women reduces the fertility rate, which in turn reduces population growth and modifies its age structure, reducing the number of children and increasing the number of young workers. For several decades, the working-age population will grow faster than the population as a whole, which will lead to lower dependency ratios. Bloom and Williamson [51] referred to this effect as a 'demographic gift'. Less dependence helps increase savings and investment $[4,37,52-54]$, which will have a positive impact on economic growth.

Similarly, higher women's education makes women more informed, contributing to reducing children's malnutrition and mortality rates $[4,5,53,55]$. Moreover, it contributes to increasing the education of the following generations, which will affect economic growth positively in the following decades $[36,42,56]$.

More recently, Hong et al. [57] empirically showed that female education and reducing gender education inequality have positive effects on various measures of sustainable development such as the health index, human development index and environmental performance as well as infant mortality and the poverty rate. However, they also found that gender gaps in education do not significantly influence economic growth.

\subsection{Inequalities in the Labour Market and Economic Growth}

The relationship between gender inequality in employment and wages and economic growth has also been addressed in the literature. These studies, however, are scarcer than those discussed in the previous section and suggest that gender labour inequalities are closely related to education gaps, and it is difficult to separate their effects. Gender differences in education can lead to employment gaps, mainly in the formal sector, where employers will prefer to hire well-trained workers and, therefore, will not employ untrained women $[8,44,50]$. Moreover, if there are barriers to women accessing a job, parents might feel that having educated daughters is not sufficiently lucrative and beneficial for the family 
and may decide not to provide further education for their daughters, leading to a gender gap in education $[40,45]$.

Most studies have found a positive relationship between better access to employment for women and economic growth $[8,9,58,59]$. Some researchers argue that gender inequalities in employment and the gap in education have similar effects on economic growth. Several reasons may explain this similarity. First, by making it difficult for women to enter the labour market, fewer talented workers are available and, therefore, the average capacity of the workforce is reduced [4,39]. Second, gender inequalities in employment can reduce economic growth through their demographic effects. Cavalcanti and Tavares [60] suggested that gender inequalities in employment are associated with higher fertility rates, a determining factor in women's lack of education, reducing economic growth. Finally, other studies focused on governance stressed that working women are generally less prone than men to corruption and nepotism $[14,40]$ and, therefore, the existence of more employed women could be beneficial for the economy.

Theoretical and empirical literature on the effects of gender inequality in wages on economic growth is quite divided. On the one hand, some studies suggested that gender equality in wages favours economic growth through greater participation of women in the labour market and a lower fertility rate $[37,60]$. Besides, women are likely to devote a greater proportion of their income to the education and health of their children [61], so lower female salaries would negatively affect the creation of human capital in society [40,49]. Similarly, higher income for women will give them greater 'bargaining power' within families that would positively affect long-term economic growth. Moreover, women are more prone to saving than men, so their higher income would be associated with greater aggregate savings in countries [62]. Finally, other authors highlighted their more efficient use of credits [8].

On the other hand, other authors have found a positive relationship between economic growth and lower female salaries. This has been tested for semi-industrialised export-oriented countries that use a large proportion of female labour with a low level of education [63-66]. The lower female salaries contribute to increasing competitiveness by reducing production costs, which favours the expansion of exports and the increase of producer benefits, stimulating investment $[65,66]$. This increase in investment and exports leads to greater economic growth. Some studies also indicated that the combination of reduced gender inequality in education and employment with high inequality in wages helps promote exports, leading to the growth of middle-income exporting countries $[10,64]$.

\subsection{Inequalities in Women's Representation in Public Institutions and Economic Growth}

Numerous research papers have addressed the effect of democracy on economic growth. Such studies, however, lead to ambiguous predictions. For some authors, the growth of a country is directly related to the number of years in which democracy has been established and the quality of the institutional environment [67]. In this vein, it is suggested that democracy can promote economic growth by encouraging investment in education and public goods. In addition, democracy imposes more restrictions on political leaders, which limits the ability of politically powerful groups to absorb the most lucrative economic opportunities [68]. It has also been argued that democracy can discourage economic growth, due to the distorting effect of redistributive policies, and the possibility of political stagnation and interest group policies.

Empirical evidence on the relationship between economic growth and democracy has also failed to reach a consensus on the effect of democracy on economic growth (see Brunetti [69] and Doucouliagos and Ulubasoglu [70] for a survey). Studies that are more recent do not resolve the controversy either. For example, Tavares and Wacziang [71], using simultaneous equations for a panel of 65 industrial and developing countries in the period 1970-1989, found that the joint effect of democracy on growth is negative and moderate. Kurzman et al. [72] claimed that democracy is an obstacle to investment because democratic regimes do not dare to impose unpopular measures to increase investment; 
only an authoritarian regime could do so. Radchi and Saidi [73] used a panel of 17 Middle East (MENA) countries for the period 2003-2012 and found that the relationship is negative and statistically significant. Papaioannou and Siourounis [74], using annual data for a panel of 166 countries during the period 1960-2009, found that democratisation leads to at least a $1 \%$ increase in the growth rate of GDP per capita. Knutsen [75] confirmed this finding. Doucouliagos and Ulubasoglu [70] concluded that the net effect of democracy on the economy does not seem to be harmful. Democracy does not have a direct impact on economic growth, but it has positive indirect effects through greater human capital, lower inflation and political instability, and higher levels of economic freedom. Tanga and Yung [76], using an Autoregressive Distributed Lag (ARDL) model for eight fast-growing Asian economies, showed that democratisation significantly affects growth, but the effect is neither consistent nor robust in all countries. Collier and Hoeffler [77] found that, in developing countries, the combination of income from natural resources and democracy has contributed to growth reduction. Narayan et al. [78] and Aisen and Veiga [79] confirmed this negative effect of democracy on growth.

The presence of women in parliaments has been often discussed as an extension of democracy, suggesting that female politicians can contribute to economic growth through the pursuit of a more egalitarian society and a better use of resources. There are different reasons why increasing the share of women in the political arena may affect economic growth [80]. On the one hand, women in politics are considered less corrupt than men [81]. This author argued that women have higher ethical standards. Furthermore, women are more risk averse than men, which leads them to be less corrupt, since corruption can be considered a risky activity. On the other hand, women's participation in politics can lead to greater infrastructure investments that address women's rights and needs, thus helping to bridge the gender gap [82].

Empirical studies that analyse the relationship between the presence of women in parliaments and economic growth are very scarce, and generally they conclude that high female representation in parliament stimulates the growth of the economy $[11,12,80]$. Thus, countries can accelerate economic growth by increasing the gender equality of their parliaments. However, these studies, use OLS (Ngwakw [83] for South Africa) or Fixed Effects estimators (Xu, [80] for Asian countries), which do not account for the potential endogeneity among the variables.

\section{Data and Methods}

\subsection{Data and Variables}

The data used in this work come from the World Bank Development Indicators database for sub-Saharan Africa (SSA), Southeast Asia (SA), Middle East (MENA), Latin America and the Caribbean (LAC) and East Asia and Pacific (EAP) countries for the period 1990-2017. Initially, we included all the countries from these geographical areas for which data on our variables of interest were available. In total, we had 105 countries (See Table A1 in Appendix A). Subsequently, we used the sub-sample made up of the SSA countries. The resulting panels were slightly unbalanced because we had a different number of observations depending on the variables that entered the estimation.

The variables included in the empirical estimates were those widely used in studies that examine gender inequality and economic growth, which were discussed in the previous section. We included the basic factors of the growth models, such as the initial conditions of the economy using the level of GDP per capita (constant 2011 international USD) to control the hypothesis of conditional convergence, the investment rate (as a percentage of GDP) and the trade openness as an indicator of the level of integration of a country within the world markets (as total exports and imports as percentage of GDP).

As for the gender inequality variables, we incorporated three different dimensions of this goal: education, labour market and female representation in public institutions. More specifically, we used the Gender Parity Index (GPI) for the gross enrolment rate in primary and secondary education to capture gender differences in education. This 
indicator expresses the ratio between girls and boys enrolled in primary and secondary levels, respectively, in public and private schools. In order to standardise the effects of the population structure by age groups, the GPI for the gross enrolment ratio for each educational level was used. Gross Enrolment Ratio (GER) or Gross Enrolment Index (GEI) is a statistical measure used in the education sector, and formerly by the UN in its Education Index, to determine the number of students enrolled in school at several different grade levels (such as elementary, middle school and high school), and to show the ratio of the number of students who live in that country to those who qualify for the particular grade level. The United Nations Educational, Scientific and Cultural Organisation (UNESCO) describes Gross Enrolment Ratio as the total enrolment within a country in a specific level of education, regardless of age, expressed as a percentage of the population in the official age group corresponding to this level of education. The GER can be over $100 \%$ as it includes students who may be older or younger than the official age group. For instance, the GER includes students who are repeating a grade, those who enrolled late and are older than their classmates or those who have advanced quickly and are younger than their classmates. This allows the total enrolment to exceed the population that corresponds to that level of education. We expected a positive sign in the coefficients of these variables.

Gender differences in labour market participation were proxied by the female-male ratio of participation in the labour force for people between 15 and 64 years. The expected result for this variable was uncertain. In some countries there may be a positive relationship between feminisation and economic growth, while in others, especially in developing countries, this association could be negative [35]. The explanation has to do with the effects that foreign trade can have on the gender employment composition as a result of the global division of labour [84].

The representation of women in public institutions was measured as the share of women in their national parliaments.

Finally, we took into account regional dummy variables to capture the specific effects of regions, which may include common institutional and geographical policies or conflicts between regions [8]. All explanatory variables were entered in the econometric estimates in logarithm form. Table 1 presents the variables and their definitions.

Table 1. Variables and definitions.

\begin{tabular}{cc}
\hline VARIABLE & DEFINITION \\
\hline GROWTHpc & GDP per capita annual growth rate based on purchasing power parity PPP (constant 2011 international USD) \\
GDPpc90 & GDP per capita based on purchasing power parity PPP (constant 2011 international USD) in 1990 \\
INV & Gross capital formation (\% of GDP) \\
OPEN & Trade (sum of imports and exports) (\% of GDP) \\
SEATS & Proportion of seats held by women in national parliaments (\%) \\
EDPRIM & School enrolment, primary (gross), gender parity index (GPI) \\
EDSEC & School enrolment, secondary (gross), gender parity index (GPI) \\
RLFP & Female-male ratio of labour force participation (15-64) \\
\hline
\end{tabular}

\subsection{Descriptive Analysis: Gender Inequalities in Different World Regions}

Before addressing the empirical strategy, it is worth highlighting some data regarding gender inequality and other variables of interest in different regions of the world. This analysis provides some preliminary insights to understand and interpret the results that we will present in later sections (see Table 2).

The regions that, on average, grew faster in the period 1990-2017 were EAP and SA. Their average annual growth rates in per capita income were 4.6 and $4.2 \%$, respectively. The SSA region had the lowest growth per capita (1.1\%). The LAC, ECA and OECD regions grew at an average annual rate of $1.4 \%$. MENA countries, meanwhile, grew at $1.6 \%$. A more detailed analysis of growth per capita by decades showed significant noteworthy trends. Table A2 (see Appendix A) presents additional information, with the decades 1990-1999, 2000-2009 and 2010-2017 standing out. The EAP and SA regions exhibited the highest 
average annual per capita growth rates during the three decades under consideration. In the 1990s, ECA countries had, on average, positive but very moderate per capita growth rates $(0.39 \%)$ because they were going through a stage of socioeconomic transition. In the following decades, the average annual growth rate increased significantly. In the 1990s, the SSA region, meanwhile, had negative annual average rates $(-0.76 \%)$, while the MENA countries registered positive rates. In the remaining decades, the growth rate in these latter two geographical areas was similar, increasing in the $2000 \mathrm{~s}$ ( 2.59 and $2.25 \%$, respectively) and decreasing in the subsequent decade (1.29\% in both cases). The LAC region exhibited the smallest variations during the three decades, registering average annual rates ranging between 1.35 and $1.59 \%$.

Table 2. Descriptive analysis. Average values 1990-2017.

\begin{tabular}{ccccccccc}
\hline VARIABLES & EAP & ECA & LAC & MENA & OECD & SA & SSA & TOTAL \\
\hline GROWTHpc & 4.567 & 1.427 & 1.465 & 1.608 & 1.454 & 4.216 & 1.087 & 2.261 \\
GDPpc90 & 4965 & 20,555 & 9885 & 11,801 & 26,949 & 1969 & 2620 & 11,249 \\
INV & 32.460 & 23.280 & 21.200 & 29.370 & 23.770 & 25.060 & 23.940 & 25.630 \\
OPEN & 45.470 & 59.580 & 34.500 & 70.250 & 41.260 & 27.280 & 51.340 & 47.100 \\
SEATS & 17.650 & 20.830 & 21.040 & 9.309 & 22.060 & 14.100 & 17.80 & 17.540 \\
EDPRIM & 0.939 & 0.985 & 0.975 & 0.829 & 0.988 & 0.804 & 0.841 & 0.908 \\
EDSEC & 0.886 & 0.986 & 1.053 & 0.781 & 0.971 & 0.670 & 0.753 & 0.871 \\
RLFP & 0.810 & 0.780 & 0.630 & 0.260 & 0.750 & 0.350 & 0.830 & 0.630 \\
\hline
\end{tabular}

Note: EAP: East Asia and Pacific; ECA: Europe and Central Asia; LAC: Latin America and Caribbean; MENA: Middle East and North Africa; OECD: OECD members; SA: South Asia; SSA: Sub-Saharan Africa.

Social indicators such as GDP per capita, number of women in parliaments, female participation in the labour market, fertility and life expectancy, generally showed positive developments over the three decades in all geographical areas. Advances in LAC, SA and SSA stand out, all being areas where there was more room for improvement. Concerning gender inequality indicators, significant progress was observed in SA, SSA and MENA countries, where the initial inequality was most severe.

Finally, Table 3 presents the correlation coefficients for the variables in Table 2. For the whole sample, correlations between variables were in general not very high and only statistically significant at the level of $10 \%$. Correlations between GPI in primary (EDPRIM) and secondary (EDSEC) education and income per capita growth (GROWTH) were 0.192 and 0.111 , respectively. The variables investment (lnINV) and proportion of seats held by women in national parliaments (lnSEATS) held also a positive and statistically significant association with growth (GROWTH) (0.348 and 0.175 , respectively).

For the SSA countries, correlation between GPI in primary education (EDPRIM) and income per capita growth (GROWTH) was somewhat higher (0.304) than in the whole sample, while between investment (lnINV) and income per capita growth (GROWTH) it was lower (0.135).

\subsection{Empirical Strategy}

The empirical strategy consisted of performing simple cross-country regressions and panel regressions. We began our analysis with a set of simple cross-country regressions in which the regressor was the average GDP per capita annual growth rate (constant 2011 international USD) for the period 1990-2017 over the set of variables described above. We were aware of the fact that endogeneity problems existed when we used simple crosssectional regressions using OLS models; however, we considered this exercise to be useful since it provided a transparent way of describing our data. The equation we used is as follows:

$$
\begin{aligned}
& \text { GROWTHpc }_{i}=\alpha+\beta_{1} \ln \text { GDPpc } 90_{i}+\beta_{2} \ln I N V_{i}++\beta_{3} \ln O P E N_{i}+\beta_{4} \ln S E A T S_{i}+\beta_{5} \ln E D P R I M_{i} \\
& +\beta_{6} \ln E D S E C_{i}+\beta_{7} \ln R L F P_{i}+\beta_{8} \text { Regions }_{i}+\varepsilon_{i}
\end{aligned}
$$


where, GROWTHpc $c_{i}$ is the GDP per capita annual growth rate based on purchasing power parity PPP (constant 2011 international USD); $\ln G D P p c 90_{i}$ the log of GDP per capita in 1990 based on purchasing power parity PPP (constant 2011 international USD); $\operatorname{lnINV} V_{i}$ the log of gross capital formation (\% of GDP); $\operatorname{lnOPEN} N_{i}$ the log of total import and export (\% GDP); $\operatorname{lnSEATS} S_{i}$ the log of the share of seats held by women in national parliaments $(\%) ; \ln E D P R I M_{i}$ the log of the gross school enrolment in primary (GPI); $\ln E D S E C_{i}$ the log of the gross school enrolment in secondary (GPI); $\ln R L F P_{i}$ the $\log$ of female-male ratio of labour force participation (15-64 years old); Regions $s_{i}$ is a dummy variable to capture regional differences, and $\varepsilon_{i}$ is the error term.

Table 3. Correlations.

\begin{tabular}{|c|c|c|c|c|c|c|c|c|}
\hline & All Countries & 1 & 2 & 3 & 4 & 5 & 6 & 7 \\
\hline 1 & GROWTHpc & 1 & & & & & & \\
\hline 2 & $\operatorname{lnINV}$ & $0.348^{*}$ & 1 & & & & & \\
\hline 3 & $\operatorname{lnOPEN}$ & -0.004 & $0.261 *$ & 1 & & & & \\
\hline 4 & $\operatorname{lnSEATS}$ & $0.175^{*}$ & -0.102 & -0.046 & 1 & & & \\
\hline 5 & $\operatorname{lnEDPRIM}$ & $0.192 *$ & $0.269 *$ & $0.185^{*}$ & 0.070 & 1 & & \\
\hline 6 & $\operatorname{lnEDSEC}$ & $0.111 *$ & 0.269 * & 0.191 * & 0.085 & $0.839 *$ & 1 & \\
\hline 7 & LnRLFP & -0.074 & -0.154 & -0.001 & $0.318^{*}$ & -0.192 & -0.191 * & 1 \\
\hline \multicolumn{9}{|c|}{ SSA countries } \\
\hline 1 & GROWTHpc & 1 & & & & & & \\
\hline 2 & $\operatorname{lnINV}$ & 0.135 * & 1 & & & & & \\
\hline 3 & $\operatorname{lnOPEN}$ & 0.171 & 0.427 * & 1 & & & & \\
\hline 4 & $\operatorname{lnSEATS}$ & 0.068 & 0.100 & 0.028 & 1 & & & \\
\hline 5 & lnEDPRIM & $0.304^{*}$ & 0.338 & 0.322 * & 0.234 & 1 & & \\
\hline 6 & $\operatorname{lnEDSEC}$ & 0.129 & 0.257 * & 0.199 & 0.203 & $0.792 *$ & 1 & \\
\hline 7 & LnRLFP & -0.157 & -0.733 & -0.055 & 0.165 & -0.173 & $-0.265^{*}$ & 1 \\
\hline
\end{tabular}

(*) Statistically significant at $5 \%$.

Subsequently, in order to control for possible problems of endogeneity, unobserved heterogeneity and autocorrelation we estimated dynamic panel regressions using a twoequation (system) GMM procedure, as in Arellano and Bover [85], with robust standard errors and the Windemeijer [86] small-sample correction, in which each observation will be the average of five years from 1990-1994 to 2014-2017 (this last period contains only four years). Thus, we had data for six periods since we were not interested in short-term cyclical effects but in the long-term structural effects.

The GMM model allowed us to control for the three major sources of endogeneity: (i) Dynamic endogeneity, which occurs when the preceding periods' values of a variable influence its values in the current period; (ii) Simultaneity, which occurs when two variables simultaneously affect each other, resulting in their co-determination; (iii) Unobserved heterogeneity that is found when the relationship between two variables is affected by some third unobservable variable. In general, these may be attributed to country-specific characteristics [87]. The GMM model removes endogeneity by internally transforming the data. By doing so, the number of observations is reduced and this process enhances the efficiency of the GMM model. Two kinds of transformation methods, known as firstdifference transformation (one-step GMM) and second order transformation (two-step GMM), can also be used as GMM estimators. The first-difference transformation has some limitations due to the fact that if a variable's recent value is missing, then the first-difference transformation can result in the loss of too many observations [88]. To avoid potential data loss owing to the internal transformation problem with the first-step GMM, Arellano and Bover [85] recommended the use of a second order transformation. This transformation applies 'forward orthogonal deviations', which means that instead of subtracting the previous observations of a variable from its current value, the two-step GMM model subtracts the average of all future available observations of a particular variable [88]. Therefore, in the case of a balanced panel data set, a two-step GMM model provides more 
efficient and consistent estimates for the coefficients involved [85]. The consistency of the parameters obtained with the GMM estimator depends on the validity of the instruments. In order to test this consistency two specification tests were considered. The first one is the Hansen test of over-identifying restrictions, which tests the null hypothesis of overall validity of the instruments used. Failure to reject this null hypothesis supports the choice of the instruments. The test for serial correlation of the error term tests the null hypothesis that the differenced error term is first and second order serially correlated. Failure to reject the null of no second order serial correlation means that the original error term is serially uncorrelated and the moment conditions are correctly specified.

The equation used is as follows.

$$
\begin{aligned}
\text { GROWTH }_{i t}=\alpha_{i} & +\beta_{1} \ln \operatorname{GDPPC} 90_{i t}+\beta_{2} \ln I N V_{i t}+\beta_{3} \operatorname{lnOPEN}_{i t}+\beta_{4} \ln S E A T S_{i t}+\beta_{5} \ln \operatorname{lDPRIM}_{i t} \\
& +\beta_{6} \ln \operatorname{EDSEC}_{i t}+\beta_{7} \ln \ln L F P_{i t}+\beta_{8} \operatorname{Regions}_{i}+\varepsilon_{i t}+\delta_{t}
\end{aligned}
$$

To capture common trends, this equation also includes country-specific intercepts $\alpha_{i}$ and time-specific fixed effects $\delta_{t}$.

\section{Results and Discussion}

\subsection{Results of the Cross-Section Model}

Table 4 presents the results of the OLS estimates for cross-sectional data for all countries. Column 1 reports the estimates from the basic specification of the growth model. In column 2, the share of women in parliament's variable is included. The specifications reported in columns 3 and 4 add variables regarding the GPI (Gender Parity Index) for primary and secondary education variables, respectively. Finally, column 5 includes the female-male ratio of labour force participation. Table 5 presents the same information for SSA countries.

Table 4. Results of cross-section regressions 1990-2017. Dependent variable: GDP per capita annual growth (constant 2011

\begin{tabular}{|c|c|c|c|c|c|}
\hline & (1) & (2) & (3) & (4) & (5) \\
\hline LnGDPpc90 & $\begin{array}{c}-0.949 * * * \\
(0.248)\end{array}$ & $\begin{array}{c}-0.944^{* * *} \\
(0.290)\end{array}$ & $\begin{array}{c}-1.124^{* * *} \\
(0.339)\end{array}$ & $\begin{array}{c}-1.124^{* * *} \\
(0.284)\end{array}$ & $\begin{array}{c}-1.031^{* * *} \\
(0.285)\end{array}$ \\
\hline $\operatorname{lnINV}$ & $\begin{array}{c}2.996^{* * *} \\
(0.927)\end{array}$ & $\begin{array}{c}3.107^{* * *} \\
(0.972)\end{array}$ & $\begin{array}{c}2.569 * * * \\
(0.788)\end{array}$ & $\begin{array}{c}3.043^{* * *} \\
(1.089)\end{array}$ & $\begin{array}{c}2.894^{* * *} \\
(0.939)\end{array}$ \\
\hline $\operatorname{lnOPEN}$ & $\begin{array}{c}0.245 \\
(0.534)\end{array}$ & $\begin{array}{c}0.164 \\
(0.552)\end{array}$ & $\begin{array}{c}0.207 \\
(0.547)\end{array}$ & $\begin{array}{c}0.144 \\
(0.511)\end{array}$ & $\begin{array}{c}0.273 \\
(0.550)\end{array}$ \\
\hline $\operatorname{lnSEATS}$ & & $\begin{array}{c}0.224 \\
(0.330)\end{array}$ & $\begin{array}{c}0.180 \\
(0.332)\end{array}$ & $\begin{array}{l}0.0546 \\
(0.330)\end{array}$ & $\begin{array}{c}0.172 \\
(0.336)\end{array}$ \\
\hline $\operatorname{lnEDPRIM}$ & & & $\begin{array}{l}4.843 * \\
(2.686)\end{array}$ & & \\
\hline $\operatorname{lnEDSEC}$ & & & & $\begin{array}{c}1.278 \\
(1.603)\end{array}$ & \\
\hline $\operatorname{lnRLFP}$ & & & & & $\begin{array}{c}-1.196 * \\
(0.604)\end{array}$ \\
\hline Constant & $\begin{array}{l}-1.329 \\
(2.915)\end{array}$ & $\begin{array}{l}-1.958 \\
(2.725)\end{array}$ & $\begin{array}{l}1.626 \\
(2.961)\end{array}$ & $\begin{array}{c}0.519 \\
(4.036)\end{array}$ & $\begin{array}{l}-1.281 \\
(2.797)\end{array}$ \\
\hline Observations & 105 & 105 & 105 & 105 & 105 \\
\hline R-squared & 0.369 & 0.363 & 0.401 & 0.390 & 0.385 \\
\hline
\end{tabular}
international USD). All countries.

Robust errors in parentheses ${ }^{* * *} p<0.01,{ }^{*} p<0.1$. Regional and time dummies are included but not reported.

The results for all countries confirmed some regularity found in the literature. In all estimations, the initial GDP per capita coefficient was negative, suggesting that the conditional convergence hypothesis was true: all other growth determinants being constant, countries with lower GDP per capita will tend to grow faster. This result was consistent with the neoclassical theories of economic growth. The investment variable was positive and statistically significant, which means that there is a positive relationship between 
capital accumulation and economic growth. This result was in line with much of the empirical literature [89]. The trade openness variable held a positive sign, but was not statistically significant. Though a strand of the empirical literature argued that greater economic interdependence is associated with greater economic growth [13,25-27,90-92], a second strand found the opposite results. In our case, the non-significance of the coefficients may be related to the period of analysis (1990-2017), since trade in goods and services underwent a very significant increase during the first three decades prior to the global financial crisis, periods in which the growth rate of international trade exceeded that of economic growth. This scenario, however, changed from 2009 on, when growth rates of international trade became smoother than those of the output.

Table 5. Results of cross-section regressions 1990-2017. Dependent variable: GDP per capita annual growth (constant 2011 international USD). SSA countries.

\begin{tabular}{|c|c|c|c|c|c|}
\hline & (1) & (2) & (3) & (4) & (5) \\
\hline LnGDPpc90 & $\begin{array}{c}-1.520 * * \\
(0.685)\end{array}$ & $\begin{array}{c}-1.518^{* *} \\
(0.707)\end{array}$ & $\begin{array}{c}-1.851^{* *} \\
(0.791)\end{array}$ & $\begin{array}{c}-1.862 * * \\
(0.762)\end{array}$ & $\begin{array}{c}-1.910 \text { ** } \\
(0.810)\end{array}$ \\
\hline $\operatorname{lnINV}$ & $\begin{array}{c}4.376^{* * *} \\
(1.531)\end{array}$ & $\begin{array}{l}4.368^{* *} \\
(1.632)\end{array}$ & $\begin{array}{c}3.783^{* * *} \\
(1.312)\end{array}$ & $\begin{array}{c}4.359^{* * *} \\
(1.600)\end{array}$ & $\begin{array}{c}3.950 * * * \\
(1.454)\end{array}$ \\
\hline $\operatorname{lnOPEN}$ & $\begin{array}{c}1.217 \\
(1.467)\end{array}$ & $\begin{array}{c}1.216 \\
(1.488)\end{array}$ & $\begin{array}{c}0.988 \\
(1.433)\end{array}$ & $\begin{array}{c}1.272 \\
(1.500)\end{array}$ & $\begin{array}{c}1.502 \\
(1.464)\end{array}$ \\
\hline $\operatorname{lnSEATS}$ & & $\begin{array}{c}0.045 \\
(0.666)\end{array}$ & $\begin{array}{l}-0.360 \\
(0.735)\end{array}$ & $\begin{array}{l}-0.235 \\
(0.717)\end{array}$ & $\begin{array}{c}0.147 \\
(0.690)\end{array}$ \\
\hline lnEDPRIM & & & $\begin{array}{l}7.282 * \\
(3.982)\end{array}$ & & \\
\hline $\operatorname{lnEDSEC}$ & & & & $\begin{array}{c}2.224 \\
(2.174)\end{array}$ & \\
\hline $\operatorname{lnRLFP}$ & & & & & $\begin{array}{c}-3.122 * \\
(1.766)\end{array}$ \\
\hline Constant & $\begin{array}{l}-5.196 \\
(4.436)\end{array}$ & $\begin{array}{l}-5.303 \\
(4.059)\end{array}$ & $\begin{array}{c}2.004 \\
(5.431)\end{array}$ & $\begin{array}{l}-1.480 \\
(6.631)\end{array}$ & $\begin{array}{l}-3.282 \\
(4.504)\end{array}$ \\
\hline Observations & 45 & 45 & 45 & 45 & 45 \\
\hline R-squared & 0.325 & 0.325 & 0.403 & 0.366 & 0.372 \\
\hline
\end{tabular}

Robust errors in parentheses ${ }^{* * *} p<0.01,{ }^{* *} p<0.05,{ }^{*} p<0.1$. Time dummies are included but not reported.

Regarding our main variables of interest, the share of women in the parliament variable was positive but not statistically significant. This result was in line with Ngwakw [83] for South Africa in the period 1998-2017 and $\mathrm{Xu}$ [80] for 28 Asian countries during the period 1991-2013. This latter author, estimating an OLS model, obtained a non-statistically significant coefficient for this variable for the years 1991-2003 and a positive coefficient for the period 2003-2013. This author argued that the insignificant coefficient could be due to the fact that the relationship between female political participation and economic growth may not be linear, meaning that the number of women in parliaments needs to reach a certain level before female representation in parliaments can influence the national economy. However, we tested this possibility and the results remained unchanged. We tested this hypothesis by adding the square of the proportion of women in parliaments. Both the linear and squared form of the variable were not statistically significant. Results are not reported, though they are available from the authors under request.

We found a positive relationship between the GPI in primary education and economic growth (Model 3). This result was consistent with part of the literature. The coefficient for the GPI in secondary education was positive, but not statistically significant (Model 4). This result can be explained by the fact that, although inequalities in secondary education have been reduced in many regions of the world, job opportunities after finishing secondary education are different for men and women [93-95]. Beyond gender gaps in schooling, girls face numerous additional challenges to receiving high-quality education. Compared to boys, girls face more barriers to staying in school, including early marriages 
and pregnancies, and greater challenges to enter the labour market [94-96]. These factors may explain, at least to some extent, the non-significant association between gender parity in secondary education and growth.

The ratio of female to male labour force participation was negative and statistically significant (Model 5). This negative result was found in Karoui and Feki [66], who referred to the sub-Saharan African countries and argued that women generally have a lower educational level than men, and thus, an increase in participation rates can displace production and economic growth. The same finding was obtained in Cabeza-García et al. [12], who studied a panel of 127 countries, highlighting the fact that most gender studies omit this variable when modelling economic growth, focusing exclusively on the effect of gender factors.

The main results for SSA countries (Table 5) were quite consistent with those for the whole sample. Coefficients for the initial conditions were, as expected, higher than for the entire sample of countries. In addition, investment seemed to be a more important determinant for economic growth in this sub-sample, because the size of the coefficient was also bigger. The same was true for education variables. This result suggests that improvements in gender parity contribute more to growth for this group of countries. Similar to the results above, the women's share of seats at the national parliament variable was positive but not statistically significant.

\subsection{Results of Dynamic Panel Model}

Table 6 presents the results of the difference GMM estimator for the entire sample. Column 1 presents the estimates from the basic specification of the model including, in addition to the initial conditions, the share of investments and trade openness. In column 2, the presence of women in national parliament variable is included. Columns 3 and 4 report variables regarding the GPI for primary and secondary education, respectively. Finally, column 5 includes the female-male ratio of labour force participation. Table 7 shows this information for SSA countries.

Table 6. Results of Dynamic models: Generalized Method of Moments (GMM) estimator. 1990-2017. Dependent variable: GDP per capita annual growth (constant 2011 international USD). All countries.

\begin{tabular}{|c|c|c|c|c|c|}
\hline & (1) & (2) & (3) & (4) & (5) \\
\hline LnGDPpc90 & $\begin{array}{c}-1.780 * * * \\
(0.344)\end{array}$ & $\begin{array}{c}-1.346^{* * *} \\
(0.507)\end{array}$ & $\begin{array}{c}-1.419 * * * \\
(0.334)\end{array}$ & $\begin{array}{c}-1.270 * * * \\
(0.416)\end{array}$ & $\begin{array}{c}-0.996^{* * *} \\
(0.347)\end{array}$ \\
\hline $\operatorname{lnINV}$ & $\begin{array}{c}6.821^{* * *} \\
(1.086)\end{array}$ & $\begin{array}{c}4.970 * * * \\
(1.362)\end{array}$ & $\begin{array}{c}4.988^{* * *} \\
(0.901)\end{array}$ & $\begin{array}{c}4.515^{* * *} \\
(1.108)\end{array}$ & $\begin{array}{c}4.369^{* * *} \\
(1.044)\end{array}$ \\
\hline $\operatorname{lnOPEN}$ & $\begin{array}{l}-1.388 \\
(0.943)\end{array}$ & $\begin{array}{l}-1.195 \\
(1.183)\end{array}$ & $\begin{array}{l}-0.945 \\
(0.596)\end{array}$ & $\begin{array}{l}-0.624 \\
(0.967)\end{array}$ & $\begin{array}{l}-1.383 \\
(0.940)\end{array}$ \\
\hline lnSEATS & & $\begin{array}{l}0.773 * \\
(0.412)\end{array}$ & $\begin{array}{l}0.668 * \\
(0.398)\end{array}$ & $\begin{array}{c}0.361 \\
(0.521)\end{array}$ & $\begin{array}{l}0.892^{* *} \\
(0.403)\end{array}$ \\
\hline $\ln E D P R I M$ & & & $\begin{array}{l}4.339 * \\
(2.229)\end{array}$ & & \\
\hline $\operatorname{lnEDSEC}$ & & & & $\begin{array}{c}4.450 * * * \\
(1.466)\end{array}$ & \\
\hline $\operatorname{lnRLFP}$ & & & & & $\begin{array}{l}-1.194 \\
(1.998)\end{array}$ \\
\hline Observations & 596 & 536 & 496 & 447 & 530 \\
\hline Number of countries & 105 & 105 & 105 & 103 & 104 \\
\hline Number of instrumental variables(IVs) & 67 & 66 & 80 & 95 & 95 \\
\hline 2nd order autocorrelation & 0.177 & 0.586 & 0.583 & 0.785 & 0.629 \\
\hline Hansen difference test & 0.061 & 0.100 & 0.102 & 0.181 & 0.253 \\
\hline
\end{tabular}

Windmeijer [86] robust standard errors in parenthesis. ${ }^{* * *} p<0.01,{ }^{* *} p<0.05$ and ${ }^{*} p<0.1$. Regional and time dummies are included but not reported. 
Table 7. Results of Dynamic models: GMM estimator. 1990-2017. Dependent variable: GDP per capita annual growth (constant 2011 international USD). SSA countries.

\begin{tabular}{|c|c|c|c|c|c|}
\hline & (1) & (2) & (3) & (4) & (5) \\
\hline LnGDPpc90 & $\begin{array}{c}0.616 \\
(1.119)\end{array}$ & $\begin{array}{c}0.769 \\
(1.037)\end{array}$ & $\begin{array}{l}-0.145 \\
(1.242)\end{array}$ & $\begin{array}{c}0.164 \\
(1.709)\end{array}$ & $\begin{array}{c}0.259 \\
(0.739)\end{array}$ \\
\hline $\operatorname{lnINV}$ & $\begin{array}{c}9.902 * * * \\
(1.209)\end{array}$ & $\begin{array}{c}11.000^{* * *} \\
(1.136)\end{array}$ & $\begin{array}{c}10.360^{* * *} \\
(1.994)\end{array}$ & $\begin{array}{c}11.500^{* * *} \\
(2.524)\end{array}$ & $\begin{array}{c}10.760 * * * \\
(1.201)\end{array}$ \\
\hline $\operatorname{lnOPEN}$ & $\begin{array}{c}-8.677^{* * *} \\
(2.255)\end{array}$ & $\begin{array}{c}-8.649^{* * *} \\
(2.021)\end{array}$ & $\begin{array}{c}-6.228^{* *} \\
(2.485)\end{array}$ & $\begin{array}{c}-7.727^{* *} \\
(3.226)\end{array}$ & $\begin{array}{c}-6.939 * * * \\
(1.699)\end{array}$ \\
\hline $\operatorname{lnSEATS}$ & & $\begin{array}{c}-2.364^{* *} \\
(1.040)\end{array}$ & $\begin{array}{l}-1.760 \\
(1.152)\end{array}$ & $\begin{array}{c}-2.135^{* *} \\
(0.995)\end{array}$ & $\begin{array}{c}-1.842 * \\
(1.094)\end{array}$ \\
\hline $\operatorname{lnEDPRIM}$ & & & $\begin{array}{c}9.901 * * \\
(4.143)\end{array}$ & & \\
\hline $\operatorname{lnEDSEC}$ & & & & $\begin{array}{l}4.001^{* *} \\
(1.944)\end{array}$ & \\
\hline $\operatorname{lnRLFP}$ & & & & & $\begin{array}{l}-4.328 \\
(4.520)\end{array}$ \\
\hline Observations & 245 & 229 & 216 & 183 & 223 \\
\hline Number of countries & 45 & 45 & 45 & 44 & 44 \\
\hline Number of instrumental variables (IVs) & 11 & 13 & 15 & 15 & 15 \\
\hline 2nd order autocorrelation & 0.891 & 0.514 & 0.824 & 0.517 & 0.627 \\
\hline Hansen difference test & 0.106 & 0.270 & 0.103 & 0.055 & 0.269 \\
\hline
\end{tabular}

Windmeijer [86] robust standard errors in parenthesis. ${ }^{* *} p<0.01,{ }^{* *} p<0.05$ and ${ }^{*} p<0.1$. Time dummies are included but not reported.

The empirical results were, to some extent, consistent with the empirical and theoretical literature and substantially compatible with the results from the previous cross-sectional analysis. Results confirmed the hypothesis of conditioned convergence in all specifications for the whole sample. The investment rate was positive and statistically significant in all specifications, which implied that this variable is highly relevant for economic growth. Trade openness was negative although not statistically significant in all regressions.

The coefficient for the share of the women in parliament variable was positive and statistically significant in most of the estimations (Models 2, 3 and 5). This positive relationship between women's presence in public institutions was in consonance with part of the empirical evidence (Jayasuriya and Burke [11], for 119 democracies for the period 1970-2009; Cabeza-García et al. [12], for a panel of 127 countries for the period 2000-2014). We tested for a non-monotonic relationship between women in parliament and growth, and the results did not support this hypothesis. We tested this hypothesis by adding the square of the share of women in parliament. Results showed that the linear and squared forms of the variable were not statistically significant except for Model 5, in which the linear term had a negative sign and the squared one had a positive sign for Model 5. This would suggest that the relationship between the proportion of women in parliaments and economic growth follows a $U$ shape, that is, that a critical proportion of women in parliaments would need to be achieved in order to contribute positively to economic growth. However, we applied the Lind and Mehlum U test [97] to robustly check the validity of this finding. This test, which examines sign and significance of a variable and of its quadratic term, showed that there was no U-shaped relationship between those variables. Results are not reported, though are available from the authors under request.

There was a positive effect of GPI for education (primary and secondary) on economic growth. This result is found in numerous studies that used different measures of education, such as Klassen and Lamana [8,50] for different world regions; Dollar and Gatti [3] for a panel of 127 countries; Klassen [4] for a group of world regions; Karoui and Feki [66] for African countries; Amin et al. [98] for a group of 107 rich and poor countries; Al-Shammari and Al Rakhis [99] for the Arab region; the results, however, were in contrast with Hong et al. [57], who did not find a statistically significant relationship between the gender gap in education and economic growth. 
When we took into account the labour-market-related variable, we observed that the coefficient was negative, although not statistically significant. Coefficients of the GPI for education were larger (and with greater statistical significance) than those of the labour force participation. This suggested that reducing the differences that persist in education may have a significant impact on economic growth.

Results for the SSA countries (Table 7) revealed that coefficients for investment were also positive and statistically significant. The sizes of these coefficients were higher than in the whole sample, which suggested that there is more scope for growth in this group of countries through increases in the investment rate. Trade openness had negative and statistically significant coefficients in all estimations. This finding seemed to be consistent with the arguments of Clemens and Williamson [28], Irwin [29] and O'Rourke [30], who found a negative relationship between trade openness and growth in the sense that they found a positive relationship between tariffs and long-term rate of growth, as noted in the theoretical section.

The proportion of women in parliaments revealed, in general, negative and statistically significant coefficients (Models 2, 4 and 5). This result was contrary to most of the literature. Empirical studies incorporating this variable were conducted with samples of countries that included both developed and developing countries. None of them addressed the case of the less economically developed regions. It is likely that the matters that are on the agendas of female parliamentarians in these countries do have an impact on women's well-being, but that these developments are not yet reflected in economic growth.

We found a positive effect of GPI for education (primary and secondary) on economic growth among SSA countries, which was in line with Baliamoune-Lutz and McGillivray [100], who studied a group of sub-Saharan African, North African and Middle Eastern countries, and with Baliamoune-Lutz and McGillivray [35], who focused on 31 sub-Saharan African and 10 Arab countries. Results suggested that in SSA countries investing in primary education tends to pay off better than investing in secondary education. The female-male ratio of labour market participation was negative, although not statistically significant.

\subsection{Discussion of the Results}

The last three decades have witnessed increasing concern about the role of women in different spheres of society, coupled with a changing global landscape. In that period, there has been some progress towards gender equality, including equal access to primary education between girls and boys, equal conditions in the workplace and the introduction of gender quotas in parliaments.

Despite this progress, gender inequalities remain pervasive in many dimensions of life worldwide. However, while disparities exist throughout the world, they are most prevalent in developing countries. International institutions recognise that it is necessary to ensure that the power and talent of women are used more extensively and effectively to provide competitive advantages in those countries [101,102]. In this vein, our results revealed that gender gaps in education hinder economic growth, which highlights the need for decisive policy action regarding female equality in education to put an end to the gender-based discrimination existing in many countries in the world, especially among developing countries.

As for women's participation in the political arena, we found that the proportion of women in national parliaments has a positive impact on economic growth for the entire sample of developing countries but a negative one for the SSA countries. Interestingly, these latter countries have experienced substantial progress since the nineties. The average proportion of women in parliament grew from $9.8 \%$ in 1995 to $22.3 \%$ in 2015 . In 1995 , no states in this region had elected women to constitute more than $30 \%$ of their single or lower houses. By 2015, the picture in the region had changed dramatically: 12 countries had elected women to more than $30 \%$ of their lower or single houses; women accounted for $40 \%$ of elected positions in five countries; and one (Rwanda) has elected women to more than $60 \%$ of their parliamentary positions [103]. 
There has been some research on whether a higher level of women's representation in parliaments has led to a different style of parliamentary politics. Most of these studies focused on western parliaments and the results of these studies were contradictory [104]. Some of these research studies have shown that women work differently than men, being more inclined to focus on grassroots activity. In addition, women have added new dimensions to the policy agenda, raising issues of equality or violence against women [105].

Little research, however, has been conducted for the least developed countries. The few studies available for SSA countries, for example, corroborate the aforementioned findings and reveal that women in the African parliaments have also added issues such as HIV / AIDS to the policy agenda, but there is little evidence to suggest that increased women's representation has changed policy outcome [106]. One reason for the weaker impact of female politicians in African countries could be the system of reserving parliamentary seats for women. Political parties usually control the quota system, and this often means that women feel they must be loyal to the party line, even at the expense of promoting gender-centred legislative reforms affecting the ability to improve the lives of women [105]. Therefore, overcoming these political barriers would be a fundamental step in enabling women in political office to develop their own management style, to introduce issues related to women's needs and rights into political agendas, and thus contribute to narrowing the gender gaps. It is very likely that the effort of female parliamentarians in some developing countries has produced changes in women's well-being (improvements in health, reduction in child mortality, reduction in female poverty, etc.). However, it might be necessary to reach a critical mass of improvement in these areas in order for these changes to be visible in terms of economic growth.

\section{Conclusions}

United Nations Sustainable Development Goals for 2015-2030 set global standards for achieving gender equality and encourage governments and civil society to implement policies aimed at reaching these standards. The focus is on achieving standards in all aspects of women's lives: education, women's participation in the labour market and women's presence in public representative institutions. We argue that progress in gender equality is not only a matter of social and economic justice, but it may also positively contribute to a more sustainable economic growth for countries. This might be particularly true in the least developed countries and those with more gender inequalities.

In this study, we examined the effects of different dimensions of gender inequalities (institutional representation, education and labour market) in income per capita growth using data from the World Bank Development Indicators database during the period 1990-2017. We focused particular attention on the less developed regions in the world by studying, firstly, a large panel made up of 105 developing countries, and, secondly, the sub-sample made up of SSA countries. We performed simple cross-country and panel regressions, these latter regressions in order to control for possible problems of endogeneity, unobserved heterogeneity and autocorrelation.

We found evidence (based on the dynamic models) that some gender inequalities hamper growth. Our results support that equality in education contributes to economic growth, and this was a common feature in both the whole sample and the sub-sample of SSA countries. The pattern we found suggests that higher GPI for the gross enrolment rate is an efficient economic option for all developing countries. In other words, countries that do not invest in women's education pay a toll in terms of slower growth. The contribution of equality in education to growth seems to be greater in the SSA countries than in the entire sample of developing countries, since the sizes of the coefficients were, in general, bigger. In addition, we found a significant link between the presence of women in parliaments and growth in the sample of all developing countries. However, this relationship was negative for the SSA countries. We have not found a significant relationship between the female-male ratio of labour force participation and growth. 
The results suggest that expanding women's educational opportunities is an effective way to promote economic growth in developing countries, including the SSA countries. Therefore, policy-makers should design inclusive policies aimed at providing education for girls through the provision of scholarships and guaranteeing compulsory schooling until a certain age. Changes in legislation and in the cultural environment should also be undertaken to enable further progress in the active engagement of women in the political arena. These changes should make it possible for women to define effective political agendas in which gender equality and the needs of women in more vulnerable situations are present. These advances are particularly necessary in the poorest countries (SSA countries) where female parliamentarians seem to encounter greater barriers to defining their political priorities.

Author Contributions: Conceptualization, A.G.-F. and C.G.-G.; Funding acquisition, A.A.; Investigation, A.A. and A.G.-F; Methodology, A.A. and C.G.-G.; Supervision, C.G.-G.; Writing-original draft, A.A. and A.G.-F.; Writing - review \& editing, A.G.-F. and C.G.-G. All authors have read and agreed to the published version of the manuscript.

Funding: The research was funded from the Research Group by the Basque Government «Institutions, Regulation and Economic Policy» (IT1052-16).

Institutional Review Board Statement: Not applicable.

Informed Consent Statement: Not applicable.

Data Availability Statement: Data sharing not applicable.

Conflicts of Interest: The authors declare no conflict of interest.

\section{Appendix A}

Table A1. List of countries.

\begin{tabular}{|c|c|c|c|c|c|c|}
\hline \multicolumn{2}{|c|}{ SSA } & \multirow{2}{*}{$\begin{array}{l}\text { MENA } \\
\text { Algeria }\end{array}$} & \multirow{2}{*}{$\begin{array}{c}\begin{array}{c}\text { LATIN } \\
\text { AMERICA }\end{array} \\
\text { Argentina }\end{array}$} & \multirow{2}{*}{$\begin{array}{c}\text { CARIBBEAN } \\
\text { Bahamas }\end{array}$} & \multirow{2}{*}{$\begin{array}{c}\text { SA } \\
\text { Afghanistan }\end{array}$} & \multirow{2}{*}{$\begin{array}{c}\text { EAP } \\
\text { Brunei Darus. }\end{array}$} \\
\hline Angola & Lesotho & & & & & \\
\hline Benin & Madagascar & Bahrain & Bolivia & Barbados & Bangladesh & Cambodia \\
\hline Botswana & Malawi & Egypt, Arab Rep. & Brazil & Belize & Bhutan & Indonesia \\
\hline Burkina Faso & Mali & Iran, Islamic Rep. & Chile & Dominican Rep. & India & Lao PDR \\
\hline Burundi & Mauritania & Iraq & Colombia & Guyana & Nepal & Malaysia \\
\hline Cabo Verde & Mauritius & Israel & Costa Rica & Haiti & Pakistan & Myanmar \\
\hline Cameroon & Mozambique & Jordan & Ecuador & Jamaica & Sri Lanka & Philippines \\
\hline Central African Rep. & Namibia & Kuwait & El Salvador & St. Lucia & & Singapore \\
\hline Chad & Niger & Lebanon & Guatemala & St. Vincent & & Thailand \\
\hline Comoros & Nigeria & Liberia & Honduras & & & Timor-Leste \\
\hline Congo, D.R. & Rwanda & Morocco & Mexico & & & Vietnam \\
\hline Congo, Rep. & Senegal & Oman & Nicaragua & & & \\
\hline Cote d'Ivoire & Seychelles & Saudi Arabia & Panama & & & \\
\hline Equatorial Guin. & Sierra Leone & Tunisia & Paraguay & & & \\
\hline Eritrea & South Africa & U. A. Emirates & Peru & & & \\
\hline Eswatini & South Sudan & & Suriname & & & \\
\hline Ethiopia & Sudan & & Uruguay & & & \\
\hline Gabon & Tanzania & & Venezuela & & & \\
\hline Gambia & Togo & & & & & \\
\hline Ghana & Uganda & & & & & \\
\hline Guinea & Zambia & & & & & \\
\hline $\begin{array}{c}\text { Guinea-Bissau } \\
\text { Kenva }\end{array}$ & Zimbabwe & & & & & \\
\hline
\end{tabular}


Table A2. Descriptive analysis for cross-section analysis by periods of 10 years.

\begin{tabular}{|c|c|c|c|c|c|c|c|c|}
\hline VARIABLES & EAP & ECA & LAC & MENA & OECD & SA & SSA & TOTAL \\
\hline GROWTHpc_1990-1999 & 3.65 & 0.39 & 1.44 & 1.18 & 1.84 & 3.30 & -0.76 & 1.58 \\
\hline GROWTHpc_2000-2009 & 4.99 & 2.23 & 1.59 & 2.25 & 1.06 & 4.23 & 2.59 & 2.70 \\
\hline GROWTHpc_2010-2017 & 5.07 & 1.60 & 1.35 & 1.29 & 1.52 & 5.23 & 1.29 & 2.48 \\
\hline GDPpc_1990-1999 & 5981 & 20,067 & 10,667 & 12,413 & 28,827 & 2235 & 2459 & 11,807 \\
\hline GDPpc_2000-2009 & 8979 & 24,975 & 12,204 & 14,913 & 34,813 & 3262 & 2804 & 14,564 \\
\hline GDPpc_2010-2017 & 14,212 & 28,424 & 14,396 & 17,434 & 37,700 & 4986 & 3420 & 17,225 \\
\hline INV_1990-1999 & 33.26 & 22.62 & 20.38 & 25.10 & 23.42 & 24.85 & 23.02 & 24.66 \\
\hline INV_2000-2009 & 30.93 & 22.21 & 19.95 & 26.21 & 22.65 & 31.41 & 21.79 & 25.02 \\
\hline INV_2010-2017 & 32.73 & 20.97 & 20.72 & 28.21 & 21.31 & 32.54 & 21.77 & 25.47 \\
\hline OPEN_1990-1999 & 43.82 & 56.50 & 33.46 & 60.50 & 39.07 & 24.12 & 46.85 & 43.48 \\
\hline OPEN_2000-2009 & 59.72 & 69.96 & 43.16 & 78.66 & 48.71 & 38.88 & 61.22 & 57.19 \\
\hline OPEN_2010-2017 & 60.41 & 79.43 & 43.93 & 81.92 & 56.11 & 46.56 & 58.07 & 60.92 \\
\hline EDPRIM_1990-1999 & 0.96 & 0.99 & 0.98 & 0.86 & 0.99 & 0.79 & 0.84 & 0.91 \\
\hline EDPRIM_2000-2009 & 0.99 & 0.99 & 0.97 & 0.92 & 0.99 & 0.93 & 0.88 & 0.95 \\
\hline EDPRIM_2010-2017 & 0.99 & 1.00 & 0.98 & 0.95 & 1.00 & 1.05 & 0.94 & 0.99 \\
\hline EDSEC_1990-1999 & 0.89 & 0.99 & 1.07 & 0.82 & 0.99 & 0.65 & 0.79 & 0.89 \\
\hline EDSEC_2000-2009 & 0.98 & 0.98 & 1.08 & 0.93 & 1.00 & 0.83 & 0.79 & 0.94 \\
\hline EDSEC_2010-2017 & 1.01 & 0.99 & 1.07 & 0.94 & 1.00 & 0.97 & 0.86 & 0.98 \\
\hline SEATS_1990-1999 & 15.99 & 15.57 & 13.68 & 3.90 & 15.47 & 6.29 & 10.56 & 11.55 \\
\hline SEATS_2000-2009 & 17.10 & 19.10 & 18.96 & 6.66 & 20.51 & 12.28 & 15.22 & 15.69 \\
\hline SEATS_2010-2017 & 18.81 & 25.09 & 26.61 & 14.66 & 26.71 & 19.60 & 22.27 & 21.96 \\
\hline FERTILITY_1990-1999 & 2.06 & 1.71 & 2.95 & 4.05 & 1.86 & 3.90 & 6.06 & 3.23 \\
\hline FERTILITY_2000 & 1.79 & 1.61 & 2.39 & 2.96 & 1.79 & 3.13 & 5.54 & 2.75 \\
\hline FERTILITY_2010-2017 & 1.80 & 1.74 & 2.12 & 2.83 & 1.75 & 2.57 & 5.02 & 2.55 \\
\hline LIFE_1990-1999 & 72.28 & 76.31 & 72.80 & 69.60 & 79.07 & 61.04 & 51.71 & 68.97 \\
\hline LIFE_2000-2009 & 75.18 & 78.15 & 76.11 & 72.80 & 81.10 & 65.61 & 54.42 & 71.91 \\
\hline LIFE_2010-2017 & 77.14 & 80.42 & 78.22 & 74.86 & 82.65 & 69.44 & 60.66 & 74.77 \\
\hline LFP_FEM_15_64_1990-1999 & 71.28 & 58.69 & 47.57 & 18.74 & 57.70 & 31.05 & 62.47 & 49.64 \\
\hline LFP_FEM_15_64_2000-2009 & 68.06 & 60.08 & 53.41 & 20.62 & 60.02 & 31.47 & 63.00 & 50.95 \\
\hline LFP_FEM_15_64_2010-2017 & 66.23 & 62.84 & 55.95 & 21.32 & 62.52 & 27.36 & 62.52 & 51.25 \\
\hline LFP_MALE_15_64__1990-1999 & 86.94 & 77.53 & 83.78 & 78.38 & 81.11 & 86.67 & 77.29 & 81.67 \\
\hline LFP_MALE_15_64_2000-2009 & 84.53 & 76.27 & 82.58 & 76.77 & 79.86 & 85.37 & 75.89 & 80.18 \\
\hline LFP_MALE_15_64_2010-2017 & 82.99 & 77.73 & 81.95 & 77.18 & 79.37 & 82.57 & 74.14 & 79.42 \\
\hline LFP_TOT_15_64_1990-1999 & 79.25 & 68.02 & 65.47 & 49.34 & 69.41 & 59.79 & 69.79 & 65.87 \\
\hline LFP_TOT_15_64_2000-2009 & 76.43 & 68.09 & 67.82 & 49.59 & 69.96 & 59.26 & 69.38 & 65.79 \\
\hline LFP_TOT_15_64_2010-2017 & 74.76 & 70.20 & 68.81 & 50.48 & 70.97 & 55.78 & 68.28 & 65.61 \\
\hline
\end{tabular}

World regions: EAP: East Asia and Pacific; ECA: Europe and Central Asia; LAC: Latin America and Caribbean; MENA: Middle East and North Africa; OECD: OECD members; SA: South Asia; SSA: sub-Saharan Africa.

Variables: GROWTH: GDP per capita annual growth rate based on purchasing power parity PPP (constant 2011 international USD); GDPpc: GDP per capita based on purchasing power parity PPP (constant 2011 international USD); INV: Gross capital formation (\% of GDP); OPEN: Trade (\% of GDP); EDPRIM: School enrolment, primary (gross), gender parity index (GPI); EDSEC: School enrolment, secondary (gross), gender parity index (GPI); FERTILITY: Total fertility rate (number of children that would be born to a woman if she were to live to the end of her childbearing years and bear children in accordance with age-specific fertility rates of the specified year; LIFE: Life expectancy at birth (number of years a newborn infant would live if prevailing patterns of mortality at the time of its birth were to stay the same throughout its life; SEATS: Proportion of seats held by women in national parliaments (\%); LFP_FEM: Female labour force participation rate (15-64); LFP_MALE: Male labour force participation rate (15-64); LFP_TOT: Total labour force participation rate (15-64); EDPRIM_FEM: Female gross enrolment ratio (primary education); EDPRIM_MALE: Male gross enrolment ratio (primary education); EDSEC_FEM: Female gross enrolment ratio (secondary education); EDSEC_MALE: Male gross enrolment ratio (secondary education). 


\section{References}

1. Pelton, J.N. Preparing for the Next Cyber Revolution; Springer: Cham, Switzerland, 2019. [CrossRef]

2. UN. The Millennium Development Goal Report; United Nations: New York, NY, USA, 2015.

3. Dollar, D.; Gatti, R.G. Gender Inequality, Income, and Growth: Are Good Times Good for Women? The World Bank Development Research Group: Washington, DC, USA, 1999. Available online: http:/ /documents.worldbank.org/curated/en/25180146876504 0122/Gender-inequality-income-and-growth-are-good-times-good-for-women (accessed on 25 March 2020).

4. Klasen, S. Low Schooling for Girls, Slower Growth for All? Cross-Country Evidence on the Effect of Gender Inequality in Education on Economic Development. World Bank Econ. Rev. 2002, 6, 345-373. [CrossRef]

5. Knowles, S.; Lorgelly, P.K.; Owen, P.D. Are Educational Gender Gaps a Brake on Economic Development? Some Cross-Country Empirical Evidence. Oxf. Econ. Pap. 2002, 54, 118-149. [CrossRef]

6. Barro, R.; Lee, J.W. International Measures of Educational Achievement. Am. Econ. Rev. 1996, 86, $218-223$.

7. Barro, R.; Sala-i-Martín, X. Economic Growth, 2nd ed.; The MIT Press: Cambridge, MA, USA, 2003.

8. Klassen, S.; Lamana, F. The impact of gender inequality in education and employment on economic growth: New evidence for a panel of countries. Fem. Econ. 2009, 15, 91-132. [CrossRef]

9. Baliamoune-Lutz, M. Globalisation and Gender Inequality: Is Africa Different? J. Afr. Econ. 2007, 16, 301-348. [CrossRef]

10. Busse, M.; Spielmann, C. Gender Inequality and Trade. Rev. Int. Polit. Econ. 2006, 14, 362-379. [CrossRef]

11. Jayasuriya, D.S.; Paul, J.; Burke, P.J. Female parliamentarians and economic growth: Evidence from a large panel. Appl. Econ. Lett. 2013, 20, 304-307. [CrossRef]

12. Cabeza-García, L.; Del Barrio, E.B.; Oscanoa-Victorio, M.L. Gender factors and inclusive economic growth: The silent revolution. Sustainability 2018, 10, 121. [CrossRef]

13. Dollar, D.; Kraay, A. Institutions, trade, and growth. J. Monet. Econ. 2003, 50, 133-162. [CrossRef]

14. Swamy, A.; Knack, S.; Lee, Y.; Azfar, O. Gender and corruption. J. Dev. Econ. 2001, 64, 25-55. [CrossRef]

15. UN. Human Development Report 2019. Beyond Income, beyond Averages, beyond Today: Inequalities in Human Development in the 21st Century; United Nations Development Programme (UNDP), 2019. Available online: http:/ /hdr.undp.org/sites/default/files / hdr2019.pdf (accessed on 17 March 2020).

16. Solow, R.M. A Contribution to the Theory of Economic Growth. Q. J. Econ. 1956, 70, 65-94. [CrossRef]

17. Romer, P.M. Increasing Returns and Long-Run Growth. J. Political Econ. 1986, 94, 1002-1037. [CrossRef]

18. Lucas, R. On the mechanics of economic development. J. Monet. Econ. 1988, 22, 3-42. [CrossRef]

19. Mankiw, N.G.; Romer, D.; Weil, D.N. A Contribution to the Empirics of Economic Growth. Q. J. Econ. 1992, 107, 407-437. [CrossRef]

20. Ipumbu, W.; Kadhikwa, G. Savings and Investment in Namibia; Bon Occasional Paper No.2; 1999. Available online: https: //www.bon.com.na/CMSTemplates/Bon/Files/bon.com.na/5c/5cb7aa02-0047-4612-9f1c-ad634bd459bc.pdf (accessed on 5 February 2020).

21. Grossman, G.M.; Helpman, E. Innovation and Growth in the Global Economy; MIT Press: Cambridge, MA, USA, 1991.

22. Young, A. Learning by doing and the dynamic effects of international trade. Q. J. Econ. 1991, 106, 369-405. [CrossRef]

23. Stokey, N.L. The volume and composition of trade between rich and poor countries. Rev. Econ. Stud. 1991, 58, 63-80. [CrossRef]

24. Spilimbergo, A. Growth and trade: The north can lose. J. Econ. Growth 2000, 5, 131-146. [CrossRef]

25. Barro, R. Economic growth in a cross section of countries. Q. J. Econ. 1991, 106, 407-443. [CrossRef]

26. Dollar, D. Outward-oriented developing economies do grow more rapidly: Evidence from 95 LDCs, 1976-1985. Econ. Dev. Cult. Chang. 1992, 40, 523-554. [CrossRef]

27. Frankel, J.A.; Romer, D. Does trade cause growth? Am. Econ. Rev. 1999, 80, 379-399. [CrossRef]

28. Clemens, M.A.; Williamson, J.G. A Tariff-Growth Paradox? Protection's Impact the World Around 1875-1997; NBER Working Paper 8459; National Bureau of Economic Research: Cambridge, MA, USA, 2001. [CrossRef]

29. Irwin, D.A. Did Import Substitution Promote Growth in the Late Nineteenth Century? NBER Working paper 8751; National Bureau of Economic Research: Cambridge, MA, USA, 2002. [CrossRef]

30. O'Rourke, K.H. Tariffs and growth in the late 19th century. Econ. J. 2000, 110, 456-483. [CrossRef]

31. Baldwin, R.E. Openness and Growth: What is the Empirical Relationship? NBER Working Paper 9578; National Bureau of Economic Research-University of Chicago Press: Cambridge, MA, USA, 2003. [CrossRef]

32. Rodriquez, F.; Rodrik, D. Trade policy and economic growth: A skeptic's guide to the gross-national evidence. In NBER Macroeconomic Annual 2000; Bernanke, B., Rogoff, K.S., Eds.; MIT Press: Cambridge, MA, USA, 2001.

33. Samman, E. Openness and Growth: An Empirical Investigation; Human Development Report Office, Occasional Paper 2005/22; United Nations Development Programme (UNDP), 2005. Available online: http://hdr.undp.org/sites/default/files/hdr2005_ samman_emma_22.pdf (accessed on 20 January 2020).

34. Wood, A. Openness and Wage Inequality in Developing Countries: The Latin American Challenge to East Asian Conventional Wisdom. World Bank Econ. Rev. 1997, 11, 33-57. [CrossRef]

35. Baliamoune-Lutz, M.; McGillivray, M. Does gender inequality reduce growth in Sub-Saharan African and Arabic countries? Afr. Dev. Rev. 2009, 21, 224-242. [CrossRef] 
36. Hill, M.A.; King, E.M. Women's Education in Development Countries: Barriers, Benefits, and Policies; World Bank Group: Washington, DC, USA, 1993. Available online: http:/ / documents.worldbank.org/curated/en/849491468740172523/Womens-education-indeveloping-countries-barriers-benefits-and-policies (accessed on 20 January 2020).

37. Galor, O.; Weil, D. The Gender Gap, Fertility, and Growth. Am. Econ. Rev. 1996, 86, 374-387.

38. Forbes, K. A Reassessment of the Relationship between Inequality and Growth. Am. Econ. Rev. 2000, 86, 374-387. [CrossRef]

39. Esteve-Volart, B. Sex Discrimination and Growth; IMF Working Paper WP/00/84; International Monetary Fund, African Department: Washington, DC, USA, 2000.

40. World Bank. Engendering Development; World Bank: Washington, DC, USA, 2001.

41. Lorgelly, P.; Owen, D. The Effect of Female and Male Schooling on Economic Growth in the Barro-Lee Model. Empir. Econ. 1999, 24, 537-557. [CrossRef]

42. Lagerlöf, N.P. Gender Equality and Long-Run Growth. J. Econ. Growth 2003, 8, 403-426. [CrossRef]

43. Abu-Ghaida, D.; Klasen, S. The Costs of Missing the Millenium Development Goals on Gender Equity. World Dev. 2004, 32, 1075-1107. [CrossRef]

44. Hakura, D.; Hussain, M.; Newial, M.; Thakoor, V.; Yang, F. Inequality, Gender Gaps and Economic Growth: Comparative Evidence for Sub-Saharan Africa; IMF Working Paper; International Monetary Fund: Washington, DC, USA, 2016; p. 111.

45. King, E.; Hill, M.A. Women's Education and Economic Well-Being. Fem. Econ. 1995, 1, 21-46. [CrossRef]

46. Goldin, C.A. Grand Gender Convergence: Its Last Chapter. Am. Econ. Rev. 2014, 104, 1091-1119. [CrossRef]

47. Angelov, N.; Johansson, P.; Lindahl, E. Parenthood and the Gender Gap in Pay. J. Labor Econ. 2016, 34, 545-579. [CrossRef]

48. Kleven, H.; Landais, C. Gender Inequality and Economic Development: Fertility, Education and Norms. Económica 2017, 84, 180-209. [CrossRef]

49. Tzannatos, Z. Women and Labor Market Changes in the Global Economy: Growth Helps, Inequalities Hurt and Public Policy Matters. World Dev. 1999, 27, 551-569. [CrossRef]

50. Klasen, S. Does Gender Inequality Reduce Growth and Development? Evidence from Cross-Country Regressions. In Policy Research Report on Gender and Development Working Paper Series; World Bank: Washington, DC, USA, 1997; Volume 7. Available online: http:/ / documents.worldbank.org/curated/en/612001468741378860/Does-gender-inequality-reduce-growth-anddevelopment-evidence-from-cross-country-regressions (accessed on 14 January 2020).

51. Bloom, D.; Williamson, J. Demographic Transition and Economic Miracles in Emerging Asia. World Bank Econ. Rev. 1998, 12, 419-455. [CrossRef]

52. Deaton, A.; Paxson, C. The Effects of Economic and Population Growth on National Saving and Inequality. Demography 1997, 34, 97-114. [CrossRef]

53. Lee, R.; Mason, A.; Miller, T. Saving, Wealth, and Population. In Population Matters: Demographic Change, Economic Growth, and Poverty in the Developing World; Birdsall, N., Kelley, A.C., Sindig, S.W., Eds.; Oxford University Press: Oxford, UK, 2001; pp. 137-164.

54. Ashraf, Q.; Weil, D.; Wilde, J. The Effect of Fertility Reduction on Economic Growth. Popul. Dev. Rev. 2012, 38, 97-130. [CrossRef]

55. Smith, L.; Haddad, L. Explaining Child Malnutrition in Developing Countries: A Cross-Country Analysis; IFPRI Discussion Papers 60; International Food Policy Research Institute: Washington, DC, USA, 1999.

56. Salatin, P.; Shaaeri, H. Impact of Gender Inequality on Economic Growth. China-USA Bus. Rev. 2015, 14, 584-591. [CrossRef]

57. Hong, G.; Kim, S.; Park, G.; Sim, S. Female education externality and inclusive growth. Sustainability 2019, 11, 3344. [CrossRef]

58. Pervaiz, Z.; Chani, M.I.; Jan, S.A.; Chaudhary, A.R. Gender Inequality and Economic Growth: A Time Series Analysis for Pakistan. Middle East J. 2011, 10, 434-439.

59. Elborgh-Woytek, K.; Newiak, M.; Kochhar, K.; Fabrizio, S.; Kpodar, K.R.; Wingender, P.; Clements, B.J.; Schwartz, G. Women, Work, and the Economy: Macroeconomic Gains from Gender Equity; Staff Discussion Note 13/10; International Monetary Fund: Washington, DC, USA, 2013.

60. Cavalcanti, T.; Tavares, J. The Output Costs of Gender Discrimination: A Model-Based Macroeconomic Estimate. Econ. J. 2015, 126. [CrossRef]

61. Morrison, A.; Raju, D.; Sinha, N. Gender Equality, Poverty and Economic Growth; Policy Research Working Paper 4349; World Bank: Washington, DC, USA, 2007. Available online: https:/ / openknowledge.worldbank.org/handle/10986/7321 (accessed on 24 January 2020).

62. Seguino, S.; Floro, M.S. Does Gender Have Any Effect on Aggregate Saving? Int. Rev. Appl. Econ. 2003, 17, 147-166. [CrossRef]

63. Cagatay, N.; Ozler, S. Feminization of the Labor Force: The Effects of Long-Term Development and Structural Adjustment. World Dev. 1995, 23, 1883-1894. [CrossRef]

64. Seguino, S. Accounting for Gender in Asian Economic Growth. Fem. Econ. 2000, 6, 27-58. [CrossRef]

65. Erturk, K.; Cagatay, N. Macroeconomic Consequences of Cyclical and Secular Changes in Feminization: An Experiment at Gendered Macro-modeling. World Dev. 1995, 23, 1969-1977. [CrossRef]

66. Karoui, K.; Feki, R. Does gender inequality reduce growth and development economique? Evidence for a panel from African countries. Qual. Quant. 2018, 52, 2055-2061. [CrossRef]

67. Gerring, J.; Kingstone, P.; Lange, M.; Sinha, A. Democracy, History, and Economic Performance: A Case-Study Approach. World Dev. 2011, 39, 1735-1748. [CrossRef] 
68. Acemoglu, D.; Robinson, J.A. Why Did the West Extend the Franchise? Democracy, Inequality, and Growth in Historical Perspective. Q. J. Econ. 2000, 115, 1167-1199. [CrossRef]

69. Brunetti, A. Political variables in cross-country growth analysis. J. Econ. Surv. 1997, 11, 163-190. [CrossRef]

70. Doucouliagos, H.; Ulubasoglu, M.A. Democracy and Economic Growth: A Meta-Analysis. Am. J. Political Sci. 2008, 52, 61-83. [CrossRef]

71. Tavares, J.; Wacziang, R. How democracy affects growth. Eur. Econ. Rev. 2001, 45, 1341-1378. [CrossRef]

72. Kurzman, C.; Werum, R.; Burkhart, R.E. Democracy's effect on economic growth: A pooled time-series analysis, 1951-1980. Stud. Comp. Int. Dev. 2002, 37, 3-33. [CrossRef]

73. Radchi, H.; Saidi, H. Democracy and Economic Growth: Evidence in MENA countries. Procd. Soc. Behv. 2015, 191, 616-621. [CrossRef]

74. Papaioannou, E.; Siourounis, G. Democratisation and growth. Econ. J. 2008, 118, 1520-1551. [CrossRef]

75. Knutsen, H.C. Which democracies prosper? Electoral rules, form of government and economic growth. Elec. Stud. 2011, 30, 83-90. [CrossRef]

76. Tanga, S.H.K.; Yung, L.C. Does rapid economic growth enhance democratization? Time-series evidence from high performing Asian economies. J. Asian Econ. 2008, 19, 244-253. [CrossRef]

77. Collier, P.; Hoeffler, A. Testing the neocon agenda: Democracy in resource-rich societies. Eur. Econ. Rev. 2009, 53, 293-308. [CrossRef]

78. Narayan, P.K.; Narayan, S.; Smyth, R. Does democracy facilitate economic growth or does economic growth facilitate democracy? An empirical study of Sub-Saharan Africa. Econ. Model. 2011, 28, 900-910. [CrossRef]

79. Aisen, A.; Veiga, F.J. How does political instability affect economic growth? Eur. J. Political Econ. 2013, 29, 151-167. [CrossRef]

80. Xu, L. Effects of Female Political Participation on Economic Growth: Evidence from Asian Countries; Lund University: Lund, Sweden, 2015.

81. Rivas, M.F. An experiment on corruption and gender. B Econ. Res. 2013, 65, 10-42. [CrossRef]

82. Coleman, I. The payoff from women's rights. Foreign Aff. 2004, 83, 80-95. [CrossRef]

83. Ngwakwe, C. Relating women in parliament and economic growth in an emerging economy-South Africa. Acta Univ. Danub. Oeconomica 2019, 15, 253-266.

84. Ertück, K.; Darity, W. Secular Changes in the Gender Composition of Employment and Growth Dynamics in the North and the South. World Dev. 2000, 28, 1231-1238. [CrossRef]

85. Arellano, M.; Bover, O. Another Look at the Instrumental Variable Estimation of Error-Components Models. J. Econom. 1995, 68, 29-51. [CrossRef]

86. Windmeijer, F. A finite sample correction for the variance of linear efficient two-steps GMM estimators. J. Econom. 2005, 126, 25-51. [CrossRef]

87. Wintoki, M.B.; Linck, J.S.; Netter, J.M. Endogeneity and the Dynamics of Internal Corporate Governance. Rev. Financ. Econ. 2012, 105. [CrossRef]

88. Roodman, D. How to do Xtabond2: An introduction to Difference and System GMM in Stata. Stata J. 2009. [CrossRef]

89. Levine, R.; Renelt, D. A Sensitivity Analysis of Cross-Country Growth Regressions. Am. Econ. Rev. 1992, 82, 942-963.

90. Dollar, D.; Kraay, A. Trade, Growth and Poverty; World Bank: Washington, DC, USA, 2001. [CrossRef]

91. Edwards, S. Openness, trade liberalization, and growth in developing countries. J. Econ. Lit. 1998, 31, $1358-1393$.

92. Sachs, J.; Warner, A. Economic reform and the process of global integration. Brookings Pap. Econ. Act. 1995, 1, 1-117. [CrossRef]

93. Grant, M.J.; Behrman, J.R. Gender gaps in educational attainment in less developed countries. Popul. Dev. Rev. 2010, 36, 71-89. [CrossRef]

94. Lloyd, C.B. New Lessons: The Power of Educating Adolescent Girls; Girls Count Report; Population Council: New York, NY, USA, 2009.

95. Psaki, S.; McCartthy, K.; Mensch, B. Measuring gender equality in education: Lesson from trends in 43 countries. Popul. Dev. Rev. 2018, 44, 11-142. [CrossRef]

96. Grant, M.J.; Hallman, K.K. Pregnancy-related school dropout and prior school performance in Kwazulu-Natal, South Africa. Stud. Fam. Plan. 2008, 39, 369-382. [CrossRef] [PubMed]

97. Lind, J.T.; Mehlum, H. With or Without U? Appropriate Test for a U-shape relationship. Oxf. Bull. Econ. Stat. 2010, 72, 109-118. [CrossRef]

98. Amin, M.; Kuntchev, V.; Schmidt, M. Gender Inequality and Growth. The Case of Rich vs. Poor Countries; Policy Research Working Paper; World Bank: Washington, DC, USA, 2016; p. 7172.

99. Al-Shammari, N.; Al Rakhis, M. Impact of gender inequality on Economic Growth in the Arab Region. J. Appl. Econ. 2017, 9. [CrossRef]

100. Baliamoune-Lutz, M.; McGillivray, M. The impact of gender inequality in education on income in Africa and the Middle East. Econ. Model. 2015, 47,1-11. [CrossRef]

101. Gonzalez, V.; De los Rios, S. Estrategia Europea 2020: Mujer, educación y empleo. CLM Econ. 2010, 17, $231-261$.

102. Nhamo, G.; Muchuru, S.; Nhamo, S. Women’s needs in new global sustainable development policy agendas. Sustain. Dev. 2018, 26, 544-552. [CrossRef] 
103. IPU -Inter-parliamentary Unión. Women in Parliament: 20 Years in Review; Inter-parliamentary Unión: Le Grand-Saconnex, Switzerland, 2015.

104. Stockemer, D. Women's Parliamentary Representation in Africa: The Impact of Democracy and Corruption on the Number of Female Deputies in National Parliaments. Econ. Political Stud. 2011, 59, 693-712. [CrossRef]

105. Devlin, C.; Elgie, R. The Effect of Increased Women's Representation in Parliament: The Case of Rwanda. Parliam. Aff. 2008, 61, 237-254. [CrossRef]

106. Dimitrova-Grajzl, V.; Obasanjo, I. Do parliamentary gender quotas decrease gender inequality? The case of African countries. Const. Political Econ. 2019, 30, 149-176. [CrossRef] 